\title{
PALEONTOLOGICAL NOTE
}

\section{First record of Elasmosaurid Plesiosaurs (Sauropterygia: Plesiosauria) in upper levels of the Dorotea Formation, Late Cretaceous (Maastrichtian), Puerto Natales, Chilean Patagonia}

\author{
Rodrigo A. Otero ${ }^{1}$, Mario E. Suárez ${ }^{2}$, Jacobus P. Le Roux ${ }^{3}$ \\ I Laboratorio de Zoología de Vertebrados, Departamento de Ciencias Ecológicas, Facultad de Ciencias, Universidad de Chile. \\ Las Palmeras 3425, Santiago, Chile. \\ paracrioceras@gmail.com \\ 2 Museo Paleontológico de Caldera. Av. Wheelwright 001, Caldera, Chile. \\ museopaleontocaldera@gmail.com \\ 3 Departamento de Geología, Facultad de Ciencias Físicas y Matemáticas, Universidad de Chile, Casilla 13518, Correo 21, Santiago, \\ Chile. \\ jroux@cec.uchile.cl
}

\begin{abstract}
New remains of plesiosaurs (Diapsida; Sauropterygia) found in a transported block correlated with upper levels of the Dorotea Formation, Late Cretaceous (Maastrichtian) are described herein. They were collected on the southern slopes of Sierra Dorotea located northeast of Puerto Natales (5141'20,4”S, 72²6'07,4”W), Magallanes Region, Chile. This is the first discovery of the family Elasmosauridae in high latitudes of South America, complementing the previously known paleodistribution of this group in the eastern Pacific Ocean and the Antarctic during the latest Cretaceous.
\end{abstract}

Keywords: Plesiosaurs, Elasmosauridae, Maastrichtian, Dorotea Formation, Magallanes, Chile.

RESUMEN. Primer Registro de Plesiosaurios Elasmosáuridos (Sauropterygia: Plesiosauria) en estratos superiores de la Formación Dorotea, Cretácico Tardío (Maastrichtiano), Puerto Natales, Patagonia Chilena. Se describen nuevos restos de plesiosaurios (Diapsida; Sauropterygia) incluidos en un bloque rodado correlacionado con estratos superiores de la Formación Dorotea (Cretácico Tardío, Maastrichtiano), recolectados en la parte sur de la sierra homónima, ubicada al noreste de Puerto Natales (5141’20,4”S, 72²6’07,4”W), Región de Magallanes, Chile. Se reconoce por primera vez la presencia de la familia Elasmosauridae en altas latitudes de Sudamérica, complementando así la paleodistribución previamente conocida de este grupo en el margen oriental del Océano Pacífico y de la Antártica durante la última parte del Cretácico Tardío. 


\section{Introduction}

Plesiosaurs (Diapsida: Sauropterygia) are Mesozoic reptiles adapted to the marine environment, with limbs modified as paddles and hydrodynamic bodies with elongated necks. Since the XIX century, previous occurrences of plesiosaurs in Chile have been widely reported in the scientific literature (Gay, 1848; Philippi, 1887; Steinmann et al., 1895; Wetzel, 1930; Colbert, 1949; Casamiquela, 1969; Gasparini, 1979). Recent studies on this group in this country and Argentina (Suárez, 2000; Gasparini and Salgado, 2000; Suárez and Fritis, 2002; Gasparini et al., 2003a) indicate that most of the regional material belongs to plesiosaurs of the Elasmosauridae family, the latter being the best represented group of marine reptiles in the Late Cretaceous of southern South America and Antarctica (Gasparini et al., 2003b).

Previous finds of elasmosaurid plesiosaurs in the uppermost Cretaceous of central Chile, came from the type localities of the Quiriquina Formation near Concepción (Gay, 1848; Steinmann et al., 1895; Wetzel, 1930; Gasparini, 1979), and from the localities of Loanco in the Maule Region, Topocalma in the O'Higgins Region, and Algarrobo in the Valparaíso Region (Suárez et al., 2003). Only one genus was recognized (Suárez and Fritis, 2002), Aristonectes Cabrera, previously recovered in Argentina (Cabrera, 1941). Other reports from Chilean Patagonia include unfigured material from the Magallanes Region (Gasparini, 1979). These are until now the southernmost records of plesiosaurs in South America.

This paper presents new material of Plesiosauria from the Late Cretaceous of Patagonia. It constitutes the first confirmed report of elasmosaurid plesiosaurs in the Maastrichtian of Magallanes, complementing previous records from central Chile with an early Maastrichtian age (Stinnesbeck, 1986). In addition, it represents the first reliable evidence of the Elasmosauridae family in an intermediate region between central Chile and Antarctica, confirming the presence of the group along the eastern margin of the Pacific Ocean during the Late Cretaceous.

Other Cretaceous elasmosaurid plesiosaurs have been reported from the Cenomanian-Turonian of Australia (Kear, 2003) and Venezuela (Colbert, 1949). They are also present in the Santonian of Japan (Sato et al., 2006) and Canada (Nicholls and Meckert, 2002). The Maastrichtian records include
New Zealand (Cruickshank and Fordyce, 2002), Japan (Ogawa and Nakaya, 1998), California (Welles, 1943), Chile (Suárez and Fritis, 2002), Argentina (Cabrera, 1941; Gasparini and Goñi, 1985) and Antarctica (Gasparini et al., 1984; Gasparini and Goñi, 1985; Chaterjee and Small, 1989), confirming that these reptiles had a worldwide distribution and a marked abundance in the Pacific at the end of the Cretaceous.

The material is hosted at the National Museum of Natural History (Museo Nacional de Historia Natural) of Santiago under the acronym SGO.PV. The few preserved bone fragments only allow them to be identified to family level. In addition, the considerable hardness of the rock constituting the host block hampers preparation of the remains, and due to the lack of more diagnostic characters, such preparation would not necessarily facilitate further identification.

\section{Source of material}

The Elasmosauridae material for this study was recovered in January 2007 during a field campaign of the Paleobotany Group of the Antarctic Ring Bicentenary Project (Proyecto Bicentenario Anillo Antártico, PBCT-ARTG-04), directed by Dr. Teresa Torres. The remains were found by the first author on the southern slopes of Sierra Dorotea (51'41'20.4'S, 72²6'07.4”W), approximately 2 kilometers NE of Puerto Natales, Magallanes Region, Chile (Fig. 1), within a transported block of calcareous sandstone found at an elevation of 243 $\mathrm{m}$ a.s.l. The block has approximate dimensions of $80 \times 50 \times 40 \mathrm{~cm}$, and a weight of about $350 \mathrm{~kg}$. The nearest outcrop of calcareous sandstone is in an inaccessible cliff higher up on the slopes of Sierra Dorotea. Field observations allow us to interpret the stratigraphic provenance of the block to be a horizon with calcareous lenses and concretionary nodules at an estimated elevation of $300 \mathrm{~m}$ a.s.1., located about $50 \mathrm{~m}$ below the top of the cliff. This lithologic unit is correlated with the upper levels of the Dorotea Formation (Katz, 1963).

\section{Geologic setting}

The stratigraphic sequence of the study area is composed, from bottom to top, of the following units (Fig. 2): 


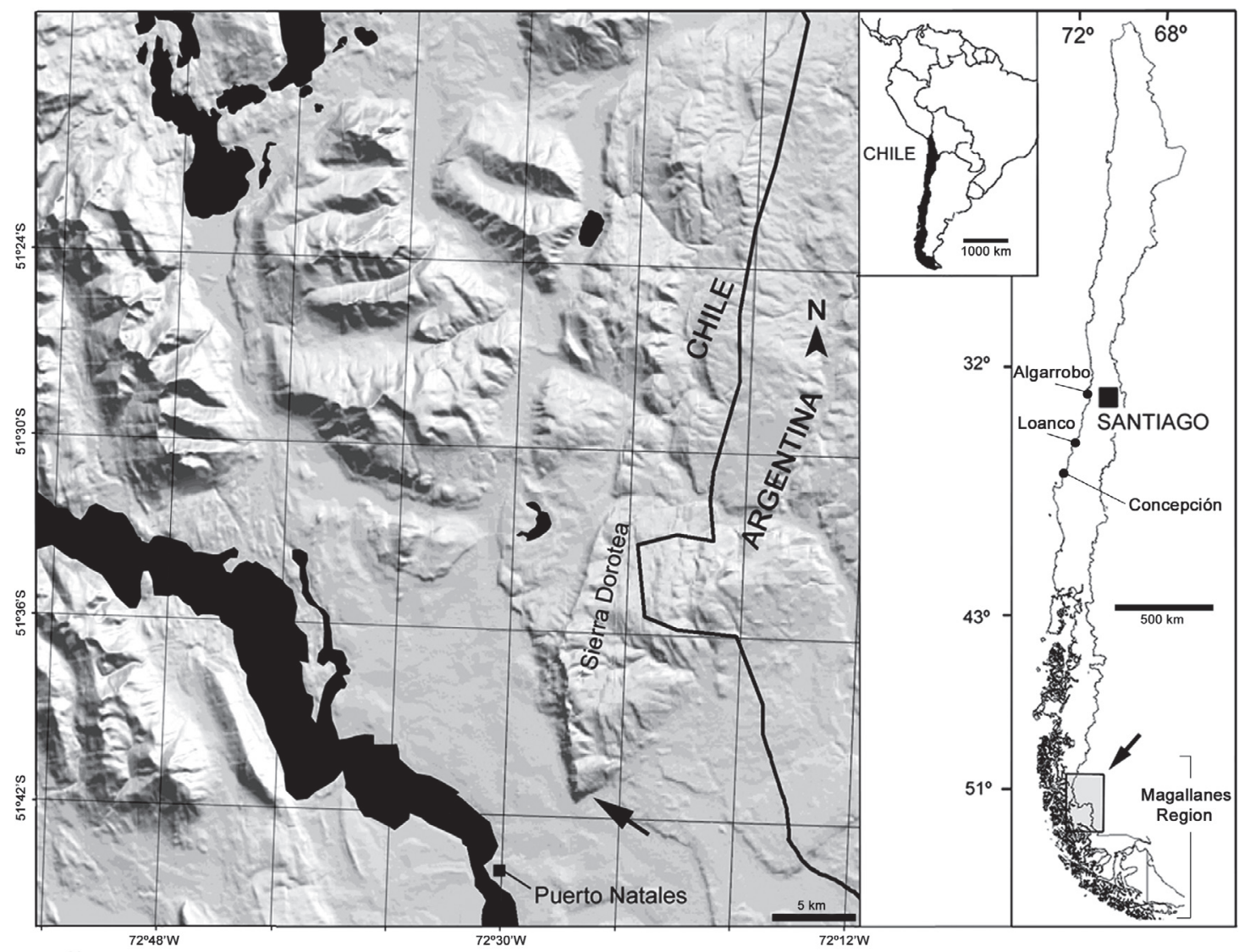

FIG. 1. ArcView based map of Puerto Natales-Seno Última Esperanza area, Magallanes, southernmost Chile. The black arrow indicates the location of Sierra Dorotea, about $2 \mathrm{~km}$ NE of Puerto Natales, where the material for this study was collected. The other Chilean localities with reports of elasmosaurid plesiosaurs are indicated on the map on the right.

Cerro Toro Formation (Cecioni, 1957). Shales, conglomerates and sandstones assigned to the Santonian-Campanian, based on ammonoids and bivalves (Hoffstetter et al., 1957) and constrained by $\mathrm{U}-\mathrm{Pb}$ dating on detrital zircons from the underlying Punta Barrosa Formation (Fildani et al., 2003). Tres Pasos Formation (Katz, 1963). Turbidites and sandstones with conglomerate lenses, assigned to the Campanian-early Maastrichtian based on ammonoids and bivalves (Katz, 1963).

Dorotea Formation (Katz, 1963). Sandstones with frequent conglomerate lenses, concretionary levels and claystones. Includes calcareous sandstones with abundant marine invertebrate and fragmentary vertebrate fossils (this study).

Río Turbio Formation (Feruglio, 1938, sensu lato; amended by Hünicken, 1955). Mainly marine sedimentary rocks of middle Eocene-late
Eocene age based on stratigraphic correlation and microfossils (Malumián and Caramés, 1997).

In the present study, the collected material of elasmosaurid plesiosaurs from the upper levels of the Dorotea Formation (Katz, 1963) was associated with a specimen of Gunnarites sp. (study in progress at the Sección de Paleontología y Estratigrafía, Servicio Nacional de Geología y Minería, SERNAGEOMIN, Chile), and a specimen of 'Pterotrigonia' cazadoriana (Wilckens) (identified by E. Pérez d'A., personal communication, 2008). Additionally, transported material was collected and identified as monocotiledons (T. Torres, personal communication, 2007). The genus Gunnarites, according to Macellari (1985), is typical of the middle to late Campanian of Seymour Island, Antarctica, but in his opinion it could extend into the Maastrichtian in Patagonia based on the record 


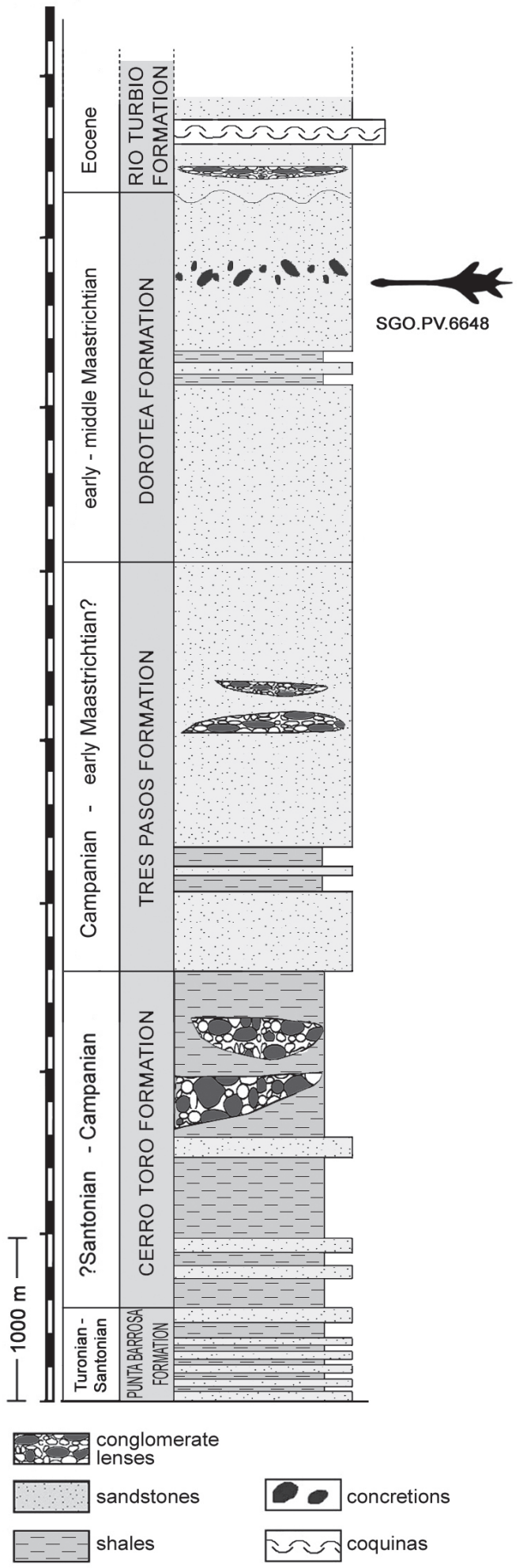

FIG. 2. General stratigraphic column of the units exposed near Puerto Natales, indicating the estimated stratigraphic position of the studied material. Thickness measures as given by Katz (1963). of this genus above beds containing Bolivinoides draco dorreeni Finlay, considered as indicative of the late Maastrichtian (Martínez-Pardo, 1965). However, according to Pérez and Reyes (1978), ' $P$.' cazadoriana could also indicate a late CampanianMaastrichtian age.

The presence of the Pachydiscus aff. gollevilensis (d'Orbigny) ammonoid, previously mentioned by Cecioni (1955), could indicate a Maastrichtian age for the Dorotea Formation (Lahsen and Charrier, 1972), although Katz (1963) noted that, according to some previous authors, the top of the formation could reach the Paleogene. In addition, Hervé et al. (2004) obtained a maximum radiometric age of $67.4 \pm 1.5 \mathrm{Ma}$ from detrital zircons contained in sandstones of the Dorotea Formation, collected at Sierra Dorotea from levels exposed near the base of the cliff (F. Hervé, personal communication, 2008). This restricts the maximum age of the horizon hosting plesiosaurs to the Maastrichtian.

\section{Systematic description}

\author{
Diapsida Osborn, 1903 \\ Sauropterygia Owen, 1860 \\ Infraorder Plesiosauria de Blainville, 1835 \\ Family Elasmosauridae Cope, 1869 \\ Elasmosauridae gen. et sp. indet. \\ (Fig. 3: A, B; Fig. 4: A, C)
}

Material: SGO.PV.6648: Seven vertebral centra, neural arches and at least six ribs, all poorly preserved. The remains are contained in a block of $80 \times 50 \times 40 \mathrm{~cm}$, consisting of very hard, finegrained, grey, calcareous sandstone (brown to reddish on weathered surfaces). The bone fragments are incomplete and the absent portions could possibly be included in an unrecovered portion of the block. The distribution and orientation of the preserved elements inside the block are irregular, resulting in different parts of the bones being exposed.

Litostratigraphic unit: Dorotea Formation (Katz, 1963), upper levels.

Age: Late Cretaceous (Maastrichtian).

Associated fauna: Gunnarites sp.; 'Pterotrigonia' cazadoriana (Wilckens).

Repository: Museo Nacional de Historia Natural, Santiago, Chile.

Description: The preserved vertebral centra are indicated from left to right in figure 3, labelled ' $v 1$ ' 

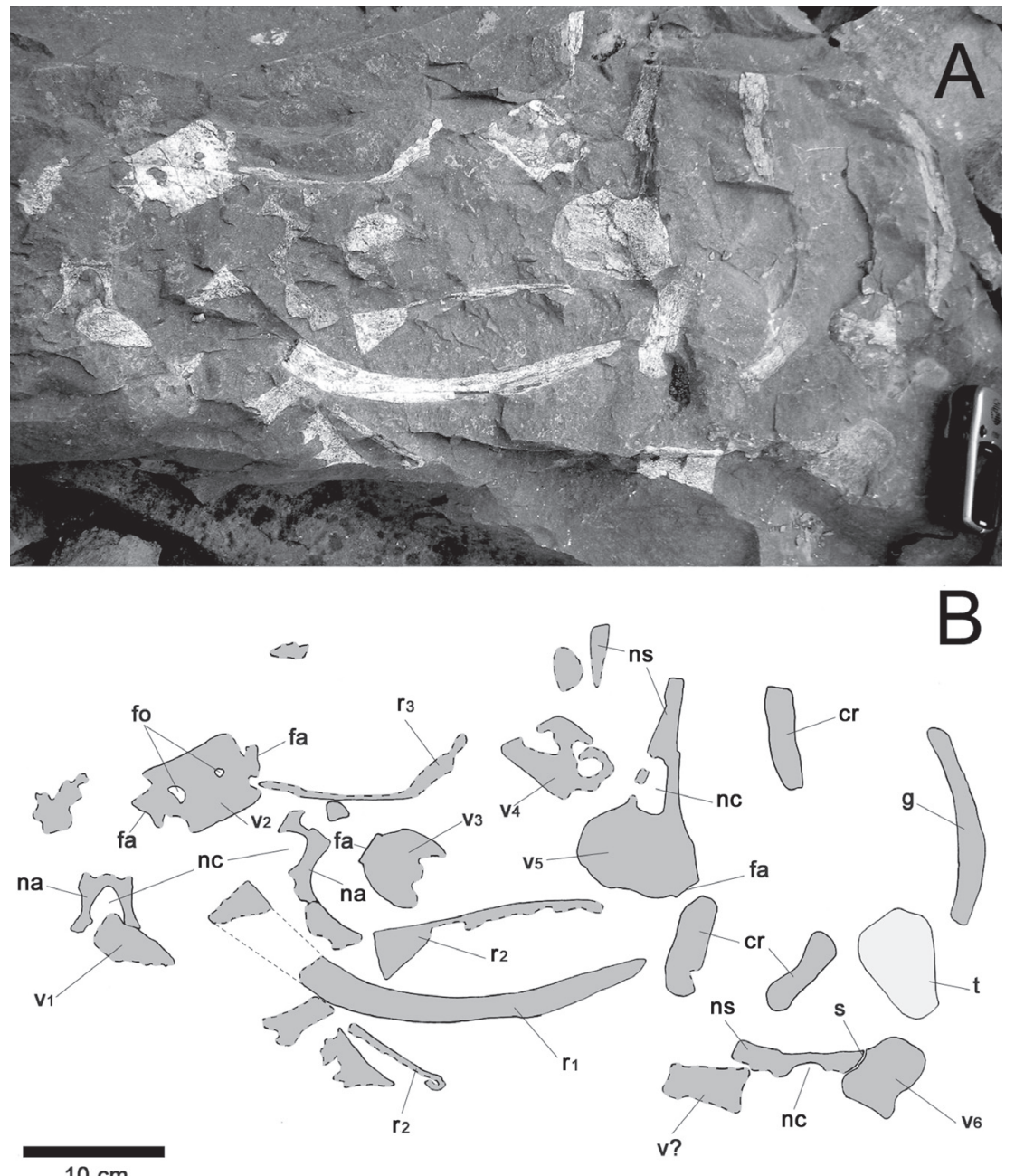

FIG. 3. A. SGO.PV.6648: Elasmosauridae gen. et sp. indet. Maastrichtian, Dorotea Formation; B. Anatomical description of the remains; fo: foraminae; fa: rib facets; na: neural $\operatorname{arch} ; \mathbf{v}^{*}$ : vertebral centra (numbered from 1 to 6$)$; $\mathbf{v}$ : possible, incomplete vertebral centrum; nc: neural channel; r*: ribs (numbered from 1 to 3 ); ns: neural spine; cr: cervical ribs; s. suture; g: possible gastralia; $\mathbf{t}$ : associated trigonid. to 'v6'. Neural arches are identified as 'na' and rib fragments as ' $r$ ', numbered from 1 to 3 . ' $v 1$ ' is a vertebral centrum with only part of its dorsal portion preserved. It is in contact with its respective neural arch ('na'). The centrum ' $v 2$ ' is clearly exposed in ventral view and shows two subcentral foraminae ('fo'). The centrum is broader than it is long, with a marked expansion of the two articular, lateral facets located in the middle portion. Vertebral centrum 'v3' is exposed in anterior-posterior view, preserving only half of its body. Nevertheless, it is possible to observe one of the lateral facets. Alongside this bone is part of a neural arch ('na') that preserves part of a centrum. The fragmentary condition and the proximity of all these elements suggest that they belong to the same vertebra. ' $\mathrm{v} 4$ ' corresponds to a deteriorated vertebral centrum exposed in oblique view, showing a higher bone density near its exterior margin. The distal portion of the neural spine is partially preserved. Vertebral centrum ' $v 5$ ' is exposed in cross-sectional view, with its respective neural spine still attached. This centrum has a dumb-bell shape and also preserves the lateral facets with one of their cervical ribs partially attached, in ventrolateral position. The neural spine is articulated and preserves the neural channel, which is elongated in a dorsal-ventral orientation.

The last vertebral centrum included in the block is ' $v 6$ ', which is exposed in right-lateral view, somewhat oblique, with both the centrum and the neural spine showing. The suture between both elements and part of the neural channel can also be observed.

Concerning the lateral bone fragments, ' $\mathrm{r}$ ' corresponds to part of a rib that almost completely preserves the contour of its distal portion. The bone 
is exposed as a longitudinal section. Its proximal end is partially preserved, but the intermediate segment between the proximal end and the rest of the rib is absent. Fragment ' $r 2$ ' is exposed in the same way as ' $\mathrm{r} 1$ ' and is also broken in two recognizable parts that can be compared and correlated as part of the same bone. Rib ' $\mathrm{r} 3$ ' is poorly preserved with a much deteriorated perimeter. Nevertheless, a higher bone density can be observed along its exterior margin.

The respective lengths observed in ' $\mathrm{r} 1$ ', ' $\mathrm{r} 2$ ' and ' $r 3$ ' seem to be all similar and indicate that these are indeed dorsal ribs of probable anterior position. The elements indicated as 'cr' are cervical ribs, one of which is associated with ' $v 5$ '. Fragment ' $\mathrm{g}$ ' has an elongated shape and regular thickness, different from that observed in typical ribs that become narrower away from their attachment. Moreover, the thickness of ' $\mathrm{g}$ ' is less than the maximum thickness observed in ' $\mathrm{r} 1$ ' and ' $\mathrm{r} 2$ ', which is why it is discarded that ' $\mathrm{g}$ ' corresponds to a rib fragment and it is rather identified as a gastralium.

The rest of the bony elements are fragments with insufficient preservation or exposure for accurate identification. The material indicated as 'v?' could possibly be interpreted as a fragmentary vertebral centrum, based on the observed straight sections similar to articular faces, and also by a higher bone density near its exterior. This, added to its posterior position from ' $\mathrm{v} 6$ ', suggests that ' $\mathrm{v}$ ?' could be a vertebral centrum.

\section{Discussion and observations}

Despite the fact that the studied material is in a poor state of preservation, it retains a group of characters that allow us to identify it as a plesiosaur of the Elasmosauridae family. The presence of ribs and a probable gastralium indicates thoraxic elements. In general, the bones could represent a part of the thorax and an incomplete vertebral sequence, with possible correlative centra ('v?'-v6').

The subcentral foraminae that are seen in centrum 'v2' in ventral view (Fig. 4A, B) correspond to a character present only in pistosaurids and all plesiosaurs (O'Keefe, 2001; Appendix I, character type No. 118). Another relevant postcraneal character is observed in the same centrum and also in cervical vertebra ' $v 6$ ', where it can be seen that the articular faces are almost flat surfaces (platycelous). The possesion of this characteristic is considered as a synapomorphy of the clade Elasmosauridae
(Bardet et al., 1999; Appendix I, postcranial characters, character No. 21). In vertebral centrum 'v6' the suture between the vertebra and its neural arch is observed. In mature individuals, the arches are strongly fused to the vertebral centrum and most of the sutures are erased (Gasparini et al., 2003b). The absence of a complete fusion between these bony elements in the studied material suggests a sub-adult condition for this individual (Brown, 1981).

Vertebral centrum ' $v 5$ ' shows a dumb-bell shape in cross-section, very similar to those seen in other elasmosaurids such as Morturneria seymourensis (Chatterjee and Small, 1989) and Aristonectes parvidens Cabrera, 1941 (Fig. 4D, E, respectively), from Seymour Island, Antarctica. Both species are considered as synonyms (Gasparini et al., 2003b). In Late Cretaceous elasmosaurids, the articular face presents this typical shape (dumb-bell), due to the development of a well-marked cavity in the ventral surface of the cervical centra. This feature is considered as a synapomorphy of Elasmosauridae (Bardet et al., 1999; Appendix I, Postcranial characters, character type No. 23).

To summarize, the presence of subcentral foraminae in the ventral part of vertebral centra allow us to include the studied material in the Plesiosauria. The flat surface of the articular faces seen in at least two vertebrae is coincident with those noted in the Elasmosauridae family. This identification is confirmed by the singular shape of the cervical centra, typical of Late Cretaceous elasmosaurid plesiosaurs.

\section{Conclusions}

The remains studied constitute the first report of plesiosaurs of the family Elasmosauridae in Magallanes, southernmost Chile. The relative age of the hosting levels of the material is assigned to the Maastrichtian based on fossil invertebrates with good chronostratigraphic resolution. Previous radiometric studies in rocks from lower levels of Sierra Dorotea (Hervé et al., 2004) indicate a maximum age of approximately 67 Ma for sandstones that crop out at the base of the cliff. This constrains the maximum age of the material to the Maastrichtian.

The occurrence of elasmosaurids, cephalopods and trigonids indicates an exclusively marine environment for the upper levels of the Dorotea Formation at the discovery site. 

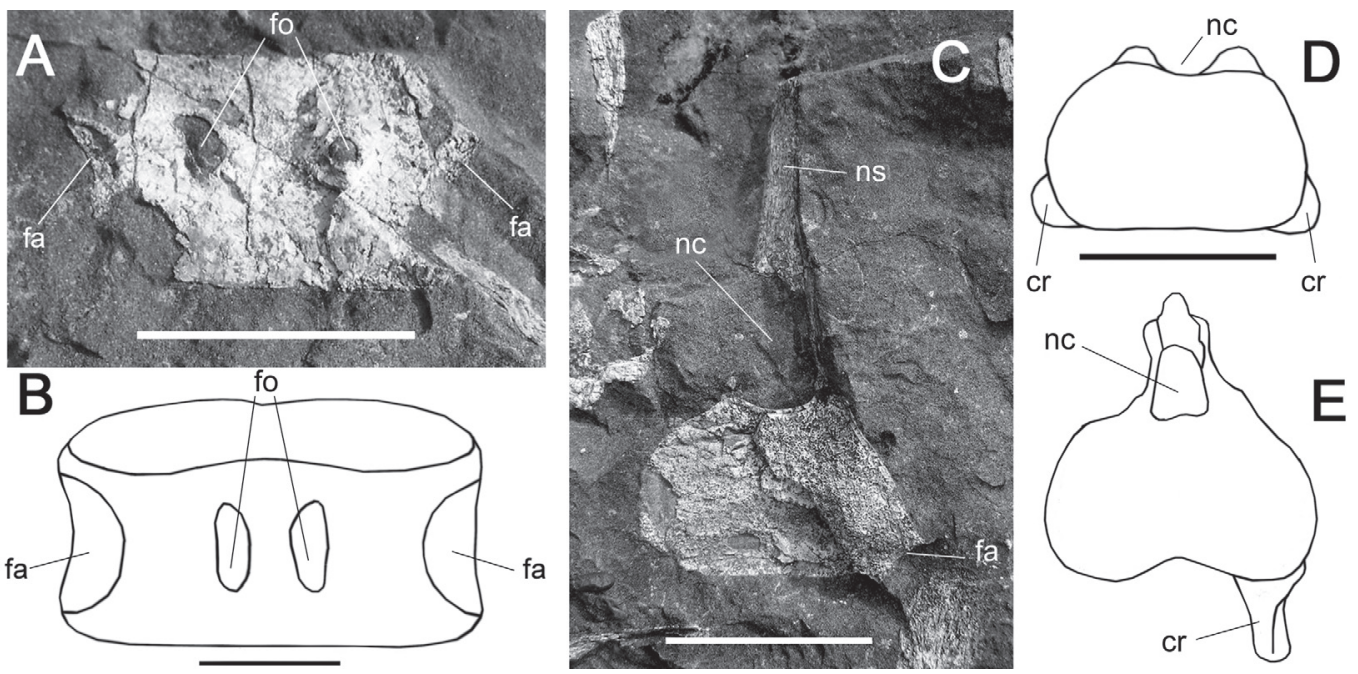

FIG. 4. Comparison of the material SGO.PV.6648 from Puerto Natales, with previous reports of Chilean material of Elasmosauridae indet. from Quiriquina Island. A. detail of the centrum ' $v 2$ ' in SGO.PV.6648; B. outline of the cervical centrum figured by Oliver-Schneider (1921), originally referred to Cimoliasaurus andium Deecke; C. detail of the centrum 'v5' in SGO.PV.6648; D. cervical vertebral centrum of an elasmosaurid plesiosaur from Seymour Island, Antarctica, and E. Aristonectes parvidens Cabrera. Note the similarity of the synapomorphic characters in the compared materials. Scale $=5 \mathrm{~cm}$. Abbreviations are the same as used in fi gure 3. B. Modified from Oliver-Schneider (1921). D. Modified from Chatterjee and Small (1989). E. Modified from Gasparini et al., 2003b.

\section{Acknowledgments}

This study is part of the Bicentenary Project of Science and Technology, Antarctic Ring Scientific Program (Proyecto Bicentenario de Ciencia y Tecnología, Programa Científico Anillo Antártico, PBCT-ARTG-04, Conicyt, Chile). The authors wish to thank especially Dr. T. Torres (Facultad de Ciencias Agronómicas, Universidad de Chile). We also wish to thank the Section of Paleontology and Stratigraphy (Servicio Nacional de Geología y Minería, SERNAGEOMIN, Chile) for their assistance with the associated fossil invertebrates. Special thanks to E. Pérez D’A. (Servicio Nacional de Geología y Minería, Chile), Dr. Z. Gasparini (Departamento de Paleontología de Vertebrados, Museo de la Plata, Argentina ) and Dr. M. Sallaberry (Departamento de Zoología, Facultad de Ciencias, Universidad de Chile), for their critical revision of the manuscript and helpful comments.

\section{References}

Bardet, N.; Godefroit, P.; Sciau, J. 1999. A new elasmosaurid plesiosaur from the Lower Jurassic of southern France. Palaeontology 42: $26 \mathrm{p}$.

Brown, D. 1981. The English Late Jurassic Plesiosauroidea (Reptilia) and review of the phylogeny and classification of the Plesiosauria. Bulletin of the British Museum (Natural History). Geological Series 4: 225-234.
Cabrera, A. 1941. Un Plesiosaurio nuevo del Cretáceo del Chubut. Revista del Museo de La Plata 2: 113-130.

Casamiquela, R. 1969. La presencia en Chile del género Aristonectes cabrera (Plesiosauria), del Maastrichtiense del Chubut, Argentina. Edad y carácter de la transgresión 'Rocanense'. In Jornadas Geológicas Argentinas, No 4, Actas 1: 199-213. Mendoza.

Cecioni, G. 1955. Distribuzione verticale di alcune Kossmaticeratidae della Patagonia cilena. Societá Geológica Italiana, Bolettino 74: 141-148.

Cecioni, G. 1957. Cretaceous flysch and molasses in Departamento Última Esperanza, Magallanes Province, Chile. American Association of Petroleum Geologists, Bulletin 41: 538-564.

Chatterjee, S.; Small, B. 1989. New plesiosaurs from the Upper Cretaceous of Antarctica. In Origins and Evolution of the Antarctic Biota (Crame, J.; editor), Geological Society, Special Publication 47: 197-215. London.

Colbert, E. 1949. Anew Cretaceous Plesiosaur from Venezuela. American Museum Novitates 1420: 1-22.

Cope, E.D. 1869. On the reptilian orders, Phytonomorpha and Streptosauria. Proceedings of the Boston Society of Natural History 12: 250-266.

Cruickshank, A.; Fordyce, E. 2002. A new marine reptile (Sauropterygia) from New Zealand: further evidence for a Late Cretaceous Austral radiation of cryptoclidid plesiosaurs. Palaeontology 45: 557-575. 
de Blainville, H.M.D. 1835. Description de quelques espèces de reptiles de la Californie précédé de l'analyse d'un système général d'erpétologie et d'amphibiologie. Nouvelles Annales du Muséum d'Histoire Naturelle de Paris, Série 3, 4: 233-296.

Feruglio, E. 1938. El Cretácico Superior de1 Lago San Martín (Patagonia) y de las regiones adyacentes. Physis 12: 293-342.

Fildani, A.; Cope, T.; Graham, S.; Wooden, J. 2003. Initiation of the Magallanes foreland basin: Timing of the southernmost Patagonian Andes orogeny revised by detrital zircon provenance analysis. Geology 31 (12): 1081-1084.

Gasparini, Z. 1979. Comentarios críticos sobre los vertebrados mesozoicos de Chile. In Congreso Geológico Chileno, No 2, Actas 3: H15-H32. Arica.

Gasparini, Z.; Goñi, R. 1985. Los plesiosaurios cretácicos de América del Sur y del continente antártico. In Congresso Brasileiro de Paleontología, No. 8, Coletanea de Trabalhos Paleontológicos, Serie Geologie 27: 55-63. Río de Janeiro.

Gasparini, Z.; Del Valle, R.; Goñi, R. 1984. An Elasmosaurus (Reptilia, Plesiosauria) of the Upper Cretaceous in the Antarctic. Boletín del Instituto Antártico Argentino 305: 1-24.

Gasparini, Z.; Salgado, L. 2000. Elasmosáuridos (Plesiosauria) del Cretácico Tardío del norte de Patagonia. Revista Española de Paleontología 15 (1): 13-21.

Gasparini, Z.; Salgado, L.; Casadío, S. 2003a. Maastrichtian plesiosaurs from northern Patagonia. Cretaceous Research 24: 157-170.

Gasparini, Z.; Bardet, N.; Martin, J.; Fernández, M. 2003b. The Elasmosaurid plesiosaur Aristonectes Cabrera from the latest Cretaceous of South America and Antarctica. Journal of Vertebrate Paleontology 23 (1): 104-115.

Gay, C. 1848. Historia Física y Política de Chile. Zoología 3-4. Imprenta Maulde y Renou: 371 p. París.

Hervé, F.; Godoy, E.; Mpodozis, C.; Fanning, M. 2004. Monitoring magmatism of the Patagonian batholith through the U-Pb SHRIMP dating of detrital zircons in sedimentary units of the Magallanes Basin. In GEOSUR, International Symposium on the Geology and Geophysics of the Southernmost Andes, the Scotia Arc and the Antarctic Peninsula (Carcione, J.; Donda, F.; Lodolo, E.; editors), Actas 4-06. In Bolletino di Geofísica Teorica ed Applicata 45 (2): 113-117. Buenos Aires.

Hoffstetter, R.; Fuenzalida, H.; Cecioni, G. 1957. ChileChili. In Lexique Stratigraphique International. Amérique Latine, Centre National de la Recherche Scientifique 5 (7): 444 p. París.

Hünicken, M. 1955. Depósitos neocretácicos y terciarios del extremo SSW de Santa Cruz. Cuenca carbonífera de Río Turbio. Revista del Instituto Nacional de Investigaciones de las Ciencias Naturales y Museo Argentino de Ciencias Naturales 'Bernardino Rivadavia’, Ciencias Geológicas 4 (1): 1-164.
Katz, H. 1963. Revision of Cretaceous stratigraphy in Patagonian Cordillera of Última Esperanza, Magallanes province, Chile. American Association of Petroleum Geologists Bulletin 47: 506-524.

Kear, B. 2003. Cretaceous marine reptiles of Australia: a review of taxonomy and distribution. Cretaceous Research 24: 277-303.

Lahsen, A.; Charrier, R. 1972. Late Cretaceous ammonites from Seno Skyring-Strait of Magellan area, Magallanes Province, Chile. Journal of Paleontology 46 (4): 520-532.

Macellari, C.E. 1985. Paleobiogeografía y edad de la fauna de Maorites-Gunnarites (Ammonoidea) del Cretácico Superior de la Antártida y Patagonia. Ameghiniana 21 (2-4): 223-242.

Malumián, N.; Caramés, A. 1997. Upper Campanian-Paleogene from the Río Turbio coal measures in southern Argentina: micropaleontology and the Paleocene/ Eocene boundary. Journal of South American Earth Sciences 10 (2): 187-201.

Martínez-Pardo, R. 1965. The presence of Bolivinoides draco dorreeni Finlay from the Magellan basin, Chile. Micropaleontology 11 (3): 360-364.

Nicholls, E.; Meckert, D. 2002. Marine reptiles from the Nanaimo Group (Upper Cretaceous) of Vancouver Island. Canadian Journal of Earth Sciences 39: 1591-1603.

Ogawa, K.; Nakaya, H. 1998. Late Cretaceous Elasmosauridae fossils from Nagakawa, Hokkaido, Japan. Bulletin of the Nakagawa Museum of Natural History $1: 3-52$.

O'Keefe, F.R. 2001. A cladistic analysis and taxonomic revision of the Plesiosauria (Reptilia: Sauropterygia). Acta Zoologica Fennica 213: 1-63.

Oliver-Schneider, C. 1921. Contribución a la Paleontología Chilena: Apuntes sobre el Cimoliasaurus andium Deecke. Revista Chilena de Historia Natural 25: 89-95.

Osborn, H.F. 1903. The reptilian subclasses Diapsida and Synapsida and the early history of the Diaptosauria. Memoirs of the American Museum of Natural History 1: 451-507.

Owen, R. 1860. On the orders of fossil and recent Reptilia and their distribution in time. Report of the British Association for the Advancement of Science 29: 153-166.

Pérez, E.; Reyes, R. 1978. Las trigonias del Cretácico Superior de Chile y su valor cronoestratigráfico. Instituto de Investigaciones Geológicas (Chile), Boletín 34: $67 \mathrm{p}$.

Philippi, R.A. 1887. Los Fósiles Terciarios i Cuartarios de Chile. Imprenta de F.A. Brockhaus: 236 p. Leipzig.

Sato, T.; Hasegawa, Y; Manabe, M. 2006. A new Elasmosaurid Plesiosaur from the Upper Cretaceous of Fukushima, Japan. Palaeontology 49 (3): 467-484.

Steinmann, G.; Deecke, W.; Möricke, W. 1895. Das Alter 
und die Fauna der Quiriquina-Schichten in Chile. Neues Jahrbuch für Mineralogie Geologie und Paleontologie 14: 1-118.

Stinnesbeck, W. 1986. Zu den Faunistischen und Palökologischen Verhältissen in der Quiriquina Formation (Maastrichtium) Zentral-Chiles. Palaeontographica (A) 194: 99-237.

Suárez, M.E. 2000. Vertebrados fósiles de la Formación Quiriquina (Cretácico Superior) de Chile. Ameghiniana, Suplemento, Resúmenes 37 (4): 33R-34R.

Suárez, M.E.; Fritis, O. 2002. Nuevo registro de Aristonectes sp. (Plesiosauroidea incertae sedis) del Cretácico Tardío de la Formación Quiriquina, Cocholgüe, Chile.
Boletín de la Sociedad de Biología de Concepción 73: 87-93.

Suárez, M.E.; Quinzio, L.A.; Fritis, O.; Bonilla, R. 2003. Aportes al conocimiento de los vertebrados marinos de la Formación Quiriquina. In Congreso Geológico Chileno, No. 10, Resúmenes: 7 p. Concepción.

Welles, S. 1943. Elasmosaurid plesiosaurs with description of new material from California and Colorado. Memoirs of the University of California 13: 125-254.

Wetzel, W. 1930. Die Quiriquina-Schichten als Sediment und Paläontologischen Archiv. Palaeontographica (A) 73: 49-106. 